\title{
FULL FAITH AND CREDIT TO JUDGMENTS: LAW AND REASON VERSUS THE RESTATEMENT SECOND
}

The United States Constitution provides: "Full Faith and Credit shall be given in each State to the public Acts, Records, and judicial Proceedings of every other State. And the Congress may by general Laws prescribe the Manner in which such Acts, Records, and Proceedings shall be proved, and the Effect thereof." Congress implemented this clause by the Act of May 26, 1790, ${ }^{2}$ which was subsequently amended and reenacted as section 1738 of the Judicial Code. This statute now provides that "Acts, records, and judicial proceedings . . . shall have the same full faith and credit in every court withm the United States and its Territories and Possessions as they have by law or usage in the courts of such State, Territory, or Possession from which they are taken."3

The American Law Institute questions the meaning of the clause and statute. Adding to the original Restatement of Conflict of Laws, ${ }^{4}$ the Second Restatement $t^{5}$ provides in section 434c, "A judgment rendered in one State of the United States need not be recognized or enforced in a sister State if such recognition or enforcement is not required by the national policy of full faith and credit because it would involve an improper infringement of the interests of the sister State." This proposition is contrary to both law and reason. This Comment will demonstrate that section $434 \mathrm{c}$ is not supported by the workmen's compensation and child custody decisions on which it is founded. Further, if taken as applicable to all judgments, section $434 \mathrm{c}$ would weaken an important federal policy of finality relating to the recognition and enforcement of judgments of other states. ${ }^{6}$ Finally, it fails to solve the problem of interstate child custody, and consequently its departure from precedent and inconsistency with constitutional policy cannot be justified.

\footnotetext{
1 U.S. Const. art. IV, § 1.

2 Ch. 11, 1 Stat. 122. The Act of March 27, 1804, ch. 56, 2 Stat. 298, supplemented the original Act by providing a detailed method of authenticating public acts, records, and judicial proceedings.

${ }^{3} 28$ U.S.C. \& 1738 (1964).

4 Restateament, Confutct of Laws (1934, Supp. 1948). The First Restatement dealt with the recognition and enforcement of judgments in $\$ \$ 429-49$. These sections, with the exception of $\S 446$, were not specifically limited to federal and sister state judgments.

5 Restateanent (SeCOND), Confuict of Laws (Tent. Draft No. 10, 1964) (Judgments) [hereinafter cited as the Restatemient, SEcond]. The Second Restatement is divided into four topics. Topics 1, 2, and 3 deal with requisites, recogmition, and enforcement of a valid judgment. According to the introductory note, topic 4 is concerned primarily with defenses to federal and sister state judgments.

${ }^{6}$ As Mr. Justice Jackson said, "[T] $]$ he full faith and credit clause is the foundation of any hope we may have for a truly national system of justice, based on the preservation but better integration of the local jurisdictions we have." Jackson, Full Faith and Credif-The Lawyer's Clause of the Constitution, 45 Corom. L. REv. 1, 34 (1945).
} 
THE LAW

Does the full faith and credit clause require recognition and enforcement of sister state judgments even when recognition infringes the interests of the forum? An initial affirmative answer was given in the landmark case of Fauntleroy v. Lum. ${ }^{7}$ A Mississippi arbitration award based on a gambling transaction in cotton futures was made in favor of one Searles. Under Mississippi law, dealing in futures constituted a misdemeanor and contracts resulting from such dealings were not enforceable in any court. Searles sued Lum in Missouri upon the award. The trial court refused to allow the latter to show the transaction illegal and void under Mississippi law and rendered judgment for the plaintiff. In a suit on the Missouri judgment ${ }^{8}$ in Mississippi, the Mississippi Supreme Court refused enforcement, stating:

We are unwilling to believe that it will ever be held that a court is precluded by the constitution of the United States from ascertaining whether the claim on which a judgment is rendered in another state is such a one as the courts of the state in which suit on the judgment is brought are, on grounds of public policy, expressly prohibited from enforcing.

The Supreme Court of the United States reversed: The illegality of the original cause of action in Mississippi could not justify denying recovery upon a sister state judgment. Writing for the majority, Mr. Justice Holmes traced the development of full faith and credit to judginents in the Court's decisions. He noted Chief Justice Marshall's remarks in Hampton v. McConnell ${ }^{10}$ that a judgment should have the same "credit, validity, and effect . . . it had in the state where it was pronounced," and that only those pleas good to a suit in the rendering state could be pleaded in any other state. ${ }^{11}$ Justice Holmes concluded that these observations were valid statements of the law and applicable to the decision in Fauntleroy v. Lum. ${ }^{12}$

7210 U.S. 230 (1908).

8 Searles assigned his judgment to Fauntleroy who brought the Mississippi action in his own name.

${ }^{3}$ Lum v. Fauntleroy, 80 Miss. 757, 763, 32 So. 290, 291 (1902).

1016 U.S. (3 Wheat.) 233 (1818). This case was decided on the authority of Mills v. Duryee, 11 U.S. (7 Cranch) 481 (1813). Mills was the first Supreme Court case interpreting the full faith and credit clause. The question was whether a plea of ril debet was good to an action on a New York judgment brought in the District of Columbia. Francis Scott Key argued for the appellant that a sister state judgment was admissible as evidence only. The Court, per Storg, J., beld the New York judgment, being final, was conclusive upon the parties.

1116 U.S. (3 Wheat.) at 235.

12210 U.S. at 236. 
Fauntleroy has been cited with approval often and was expressly followed in Kenney v. Supreme Lodge of the World, ${ }^{13}$ Roche $v$. McDonald, ${ }^{14}$ Morris v. Jones, ${ }^{15}$ and Union Nat'l Bank v. Lamb. ${ }^{16}$ Its principle has not been weakened by subsequent decision.

The Second Restatement nevertheless takes the position that there are "extremely rare occasions ... when recognition of a sister State judgment would require too large a sacrifice by a State of its interests in a matter with which it is primarily concerned."17 On such occasions, this "improper infringement" theory allows a sister state judgment to be ignored. ${ }^{18}$

The Reporter's Note for section $434 c^{10}$ advances two justifications for the "improper infringement" exception: ${ }^{20}$ first, a national policy for the protection of the fundamental interests of a state, the Reporter relying on the opinions of Justice Stone in Yarborough v. Yarborough, ${ }^{21}$ Milwaukee County v. M. E. White Co., ${ }^{22}$ and Magnolia Petroleum Co.

13252 U.S. 411,415 (1920).

14275 U.S. 449,454 (1928).

15329 U.S. 545,553 (1947).

16337 U.S. 38, 41 (1949).

17 RESTATEMnent, SeCOND \& 58.

18 This theory, the progeny of Stone's dissent in Yarborough v. Yarborougb, 290 U.S. 202, 215 (1933), is enunciated in a law review article co-authored by Professor Willis Reese. Reese \& Johnson, The Scope of Full Faith and Credit to Judgments, 49 Colus. L. Rev. 153 (1949) (erroneously cited in the Second Restatement as "49 Caxtr. L. REv. 153 (1959)."). Aside from the change of wording from "forbidden" to "improper," the rule of $\& 434 \mathrm{c}$ is identical to the theory set forth in the article. The authors rely on the following cases: Krieger v. Krieger, 334 U.S. 555 (1948) (New York maintenance decree bcld to survive a Nevada divorce, although that divorce was recognized as terminating the marriage); Esenwein v. Commonwealth ex rel. Esenwein, 325 U.S. 279 (1945); Williams v. North Carolina, 325 U.S. 226 (1945). They feel that Esenwein and Williams can be explained on no other grounds but the "forbidden infringement" exception to full faith and credit. Reese \& Johnson, supra at 171 . These cases, however, deal solely with the question of jurisdiction as a prerequisite to a valid judgment entitled to full faith and credit and, therefore, do not seem in point. In addition, the authors cite Industrial Comm'n v. McCartin, 330 U.S. 622 (1947); New York ex rel. Halvey v. Halvey, 330 U.S. 610 (1947); Magnolia Petroleum Co. v. Hunt, 320 U.S. 430 (1943); Yarborough v. Yarborough, 290 U.S. 202 (1933), all of which are discussed in the text accompanying notes 19-40 infra. Commenting on the validity of their proposed exception, the authors state: "To date, it can fairly be said that this theory is one that has often been hinted at in the cases, but rarely applied." Reese \& Johnson, supra at 171 . And, "in the absence of case precedent, it seems impossible to do more than suggest that such an exception ... does in all probability exist." Reese \& Johnson, supra at 178.

19 The Second Restatement, after stating the rule in $\S 434 \mathrm{c}$, includes comments dealing with the scope and rationale of the rule. A Reporter's Note then presents authority for the rule and comments. For reasons of convenience the cases cited will be analyzed according to the manner in which they are grouped in $\S 434 \mathrm{c}$.

20 The scope of this section is said by its authors to be "uncertain." Restatement, SECOND $\S 434 c$, comment a.

21290 U.S. 202, 213 (1933) (dissenting opinion).

22296 U.S. 268, 273-74 (1935) (dictum). 
v. Hunt, ${ }^{23}$ and also citing Industrial Comm'n v. McCartin; ${ }^{24}$ second, some other national policy, the Reporter relying on the concurring opinions of Justice Rutledge in Nere York ex rel. Halvey v. Halvey, ${ }^{25}$ and Justice Frankfurter in May v. Anderson. ${ }^{26}$ However, these authorities do not support section 434c.

In Yarborough, a Georgia divorce decree awarded permanent alimony of 1,750 dollars to Sadie, the child of the marriage. Under Georgia law, a divorce decree could unalterably fix the extent of support a father owed his child during minority. Sadie sued her father in South Carolina for additional support, ${ }^{27}$ and he set up the Georgia decree as a bar to the action. The trial court rejected this defense and ordered further support; its decision was affirmed by the Supreme Court of South Carolina. The United States Supreme Court reversed, holding full faith and credit due the Georgia decree. Mr. Justice Stone, dissenting, said: "In the assertion of riglits, defined by a judgment of one state, within the territory of another, there is often an inescapable conflict of interest of the two states, and there comes a point beyond which the imposition of the will of one state beyond its own borders involves a forbidden infringement of some legitimate domestic interest of the other." ${ }^{\prime 28}$ At this point, the Justice believed, the Supreme Court "must determine for itself the extent to which one state may qualify or deny rights clained under proceedings or records of other states."29 As a dissent, Justice Stone's opinion cannot fairly be relied on as authority for section 434c.

In Milwaukee County v. M. E. White Co., ${ }^{30}$ a Wisconsin judgment for taxes duly assessed against an Illinois corporation was held entitled to full faith and credit in Illinois. ${ }^{31}$ In Magnolia Petroleum Co. v.

23320 U.S. 430, 438 (1943) (dictum).

24330 U.S. 622 (1947).

25 Id. at 619.

26345 U.S. 528, 535 (1953).

27 Jurisdiction over the defendant was obtained first by attachment of his property and subsequently by personal service. 290 U.S. at 204.

28 Id. at 215. This passage seems to be the basis of the term "improper infringement" found in $\$ 434 \mathrm{c}$. See note 18 supra.

$29 \mathrm{Ibid}$. Even if Justice Stone's opinion is considered to lead to a more desirable result, his "forbidden infringement" proposal offers at best an alternative ground. Since Sadie was never made a party to the Georgia action, or served with process, or represented by a guardian ad litem, the same result could have been reached inore persuasively on the grounds of lack of jurisdiction and lack of representation of the minor child "without impairing the hard-won ironclad principle of jull faith and credit, established in Fauntleroy v. Lum half a century ago." EmREnzWEIG, Confuct of Laws \& 56, at 205 (1962).

30296 U.S. 268 (1935).

31 Taxation under the full faith and credit clause had heretofore been in doubt due to 
Hunt, ${ }^{32}$ a Louisiana resident employed by a Louisiana corporation was injured in Texas and received an award of workmen's compensation there. Because Texas gives final workmen's compensation awards the force and effect of judgments, ${ }^{33}$ the Supreme Court refused to permit the plaintiff to sue for additional compensation in Louisiana. The Second Restatement can rely on Milwaukee and Magnolia for its novel proposition only because Mr. Justice Stone, who wrote both opinions, included in each an assumption that the Constitution's command is not "all-embracing." 34 To be sure, the doctrine of full faith and credit is subject to certain defenses, such as lack of jurisdiction ${ }^{35}$ and lack of finality of judgment, ${ }^{36}$ but the result of these two cases does not admit of a further exception.

The Second Restatement's use of Industrial Comm'n v. McCartin ${ }^{37}$ in support of the "improper infringement" theory is inappropriate. ${ }^{88}$ McCartin is factually similar to Magnolia, except the initial workmen's compensation award was made in the state of the plaintiff's residence (Illinois) and additional compensation was made in the state of injury (Wisconsin). But the statute and the initial award in McCartin, in contrast to Magnolia, did not purport to himit further claims arising out of the same accident. ${ }^{30}$ The Court in McCartin permitted a subsequent award in Wisconsin, stating that if similarities of statute and award existed, Magnolia would control. ${ }^{40}$ Since there were such marked differences, the results, too, differed. McCartin is, therefore, no source for the Second Restatement's exception to full faith and credit.

On the basis of these authorities, one can say only that the Court has not entirely foreclosed the possibility of permitting an exception to full faith and credit based on local public policy. Such a case, while

the statement of Chief Justice Marshall that "the courts of no country execute the penal laws of another." The Antelope, 23 U.S. (10 Wheat.) 66, 123 (1825).

32320 U.S. 430 (1943).

33 Id. at 435.

${ }^{34}$ The same phrase was used in both decisions. Milwaukee County v. M. E. White Co., 296 U.S. 268, 274 (1935) ; Magnolia. Petroleum Co. v. Hunt, 320 U.S. 430, 438 (1943).

35 E.g., Williams v. North Carolina, 325 U.S. 226 (1945); see note 18 sutpra.

36 E.g., Lynde v. Lynde, 181 U.S. 183, 187 (1901) ; Barber v. Barber, 323 U.S. 77, 80

(1944) (dictum); Sistare v. Sistare, 218 U.S. 1,17 (1910) (dictum).

37330 U.S. 622 (1947).

38 Restatement, SeCONd \& 59.

39 Industrial Comm'n v. McCartin, 330 U.S. 622, 627 (1947): "But there is nothing in the statutes or $m$ the decisions thereunder to indicate that it is completely exclusive, that it is designed to preclude any recovery by proceedings in another state for injuries received there in the course of an Illinois employment." Id. at 629. The award was based on a settlement agreement approved by the Commissioner which stated in part: "This settlement does not affect any' rights that applicant. may have under the Workmen's Compensation Act of the State of Wisconsin." lbid.

$40 \mathrm{Id}$. at 626. 
conceivable, has never arisen. Apart from the language of dissenting opinions and dicta, no authority supports the improper infringement exception to full faith and credit.

Authority for the second ground of section $434 \mathrm{c}$ - "some other national policy"41-is said to be found in the concurring opinions in New York ex rel. Halvey v. Halvey ${ }^{42}$ and May v. Anderson. ${ }^{43}$ These cases deal with problems of interstate child custody decrees, and the Second Restatement apparently means to indicate by citing them ${ }^{44}$ that these decrees need not be given full faith and credit. The Supreme Court, however, has not so declared.

In Halvey, modification by New York of a Florida custody decree was upheld since the decree was modifiable in the rêndering state. The Court expressly reserved the question of full faith and credit-whether New York's power to modify could be greater than that allowed by Florida. Justice Rutledge concurred in the result but expressed his belief that as a matter of both local and federal policy, the controlling consideration slould be the best interests of the child and, in view of this, further litigation would be undesirable. Nevertheless, he felt that unless a judgment purported finality, full faith and credit would not prevent a subsequent lawsuit. ${ }^{45}$

In May v. Anderson, it was held that Ohio in a liabeas corpus proceeding, need not recognize a custody decree obtained as part of an ex parte Wisconsin divorce. Justice Burton, writing for himself and three others, stressed the lack of in personan jurisdiction and consequent lack of due process. ${ }^{46}$ It was Justice Frankfurter, concurring, who said that full faith and credit was not due this custody decree. $\mathrm{He}$ argued that a state's responsibility toward children is of paramount importance and "is obviously not to be foreclosed by a prior adjudication reflecting another State's discharge of its responsibility at another time." $\$ 47$

41 The precise meaning of this phrase is not explained. Assumedly it refers to the feeling expressed in some cases that the welfare of a child of a broken marriage should take precedence over what are often considered hyper-technical rules regarding the enforcement of foreign judgments.

42330 U.S. 610,619 (1947).

43345 U.S. 528,535 (1953).

44 Restatearent, Second $\$ 434$ c, Reporter's Notes at 59.

45330 U.S. at 621 (1947) (concurring opinion).

46345 U.S. at 533. Because in Ohio habeas corpus is an appropriate procedure only for determining the immediate possession of the child and not the general question of custody, Professor Currie was of the opinion that May v. Anderson should be narrowly limited to the circumstances of the case. Currie, Full Faith and Credit Chiefly to Judgments: A Role for Congress, 1964 Supreare Court Rev. 89.

47345 U.S. at 536 (1953). 
The limited significance of Justice Frankfurter's opinion should be noted. He spoke only of custody decrees and not of judgments in general; ${ }^{48}$ nor did he use language such as "improper infringement" or "sacrifice" ${ }^{40}$ of a state's interest. Additionally, since a Wisconsin custody order is always subject to modification, ${ }^{60}$ it cannot be claimed that this concurring opinion, even if approved by the Court, would have answered the question left open in Halvey.

Nor do Kovacs v. Brezerer ${ }^{51}$ and Ford v. Ford ${ }^{52}$ bear out the proposition of the Second Restatement. In Kovacs, North Carolina declined to follow a New York custody decree previously modified in New York. The Court "explicitly reserved" the constitutional question and remanded to clarify the question of changed circumstances. ${ }^{53}$ In lis dissent, Frankfurter, arguing as he had in May v. Anderson, rejected the notion of full faith and credit to custody decrees. ${ }^{54}$ But a dissenting opinion in a case involving a modifiable decree cannot be classified as a general principle of constitutional law.

In Ford, the Court again refused to pass upon the constitutional question reserved in Kovacs v. Brewer. A dismissal of a custody suit had been ordered in Virginia because the spouses lad reached an agreement. Subsequently, a custody action was brought in South Carolina. The trial court awarded custody of the children to the wife contrary to the Virginia agreement on which the husband based his defense. The South Carolina Supreme Court reversed, holding that under Virginia law and the full faith and credit clause, the Virginia order of dismissal was binding..$^{55}$ The United States Supreme Court reversed on the narrow ground that the South Carolina court had misinterpreted Virginia law.

Contrary to the claims of the Second Restatement the Supreme Court has not created an exception to full faith and credit in the area of child custody decrees. In fact, the Court has studiously avoided adjudicating this question, preferring to discuss the cases in terms of juris-

\footnotetext{
${ }^{48}$ Section $434 \mathrm{c}$ indicates no limitation of application based upon the nature of the judgment under consideration.

49 Restatement, Second $\$ 434 \mathrm{C}$.

50 Wis. Stat. ANno. $\$ 247.24$ (1957). Though neither party argued on the basis of this statute, it has been in existence since 1849.

51356 U.S. 604, 609 (1958).

52371 U.S. 187 (1962). This case was not cited by the Second Restatement, but because of its importance to a full discussion of the law in the field of recognition of child custody decrees it has been included here.

63356 U.S. at 608. On remand, the North Carolina court, informed that the father bad died, found the case moot. Kovacs v. Brewer, 248 N.C. 742, 104 S.E.2d 882 (1958).

54356 U.S. at 609.

55239 S.C. $305,317,123$ S.E.2d 33, 39 (1961).
} 
diction and finality of judgment. This is not to say that the Supreme Court could not declare that custody decrees are not entitled to full faith and credit, only that it has not yet done so.

That a trend is discernible toward greater discretion in the recogmtion of custody decrees is not disputed. ${ }^{56}$ The cases, however, do not warrant stating that trend as a rule of law and as a general exception to the constitutional requirement of full faith and credit to judgments. ${ }^{57}$

\section{II \\ REASON}

On policy grounds the proposition of the Second Restatement suffers from two major mfirmities: First, it creates a constitutional exception to the recognition of sister state adjudications which could have undesirable repercussions. Second, it does not present an adequate solution to the problems facing the courts in child custody cases.

The full faith and credit clause has an important function in our federal system, for it provides a method of avoiding stalemates and interminable litigation by requiring recognition of sister state judgments, despite the forum state's policy on the underlying substantive issue. ${ }^{.8}$ Makmg exceptions to this clause as a means of solving problems in the field of child custody or, indeed, in any field where state interest is great, is likely to meet with little success and may prove detrimental to our federal system. ${ }^{59}$

50 See Ehrenzweig, Interstate Recognition of Custody Decrees, 51 Micr. L. Rev. 345 (1953). See also Stansbury, Custody and Maintenance Laws Across State Lines, 10 LAw \& Contearp. Prob. 819 (1944).

57 Professor Ratner best summarized the present situation by saying, "The protection afforded a custody decree by the full faith and credit clause is uncertain." Ratner, Child Custody in a Federal System, 62 MICH. L. REv. 795, 807 (1962).

58 In one early case the Supreme Court said, "When ... the confederation was being formed, it was seen by the wise men of that day that the powers necessary to be given to the confederacy, and the rights to be given to the citizens of each state, in all the states, would produce such intimate relations between the states and persons, that the former would no longer be foreign to each other in the sense that they had been, as dependent provinces; and that, for the prosecution of rights in courts, it was proper to put an end to the uncertainty upon the subject of the effect of judgments obtained in the different states." McElmoyle v. Cohen, 38 U.S. (13 Pet.) 312, 325 (1839). See also Nadelmann, Full Faith and Credit to Judgments and Public Acts, 56 MicH. L. Rev. 33 (1957). See generally Costigan, The History of the Adoption of Section 1 of Article IV of the United States Constitution and a Consideration of the Effect on Judgments of that Section and of Federal Legislation, 4 Colum. L. Rev. 470 (1904).

69 Professor Currie has noted: "[J]udicially created exceptions to the command of full faith and credit are undesirable; the modern trend has been to eliminate such exceptions, not to multiply them.... [T] [Te principle of full faith and credit has not been helpful in preventing such disorders, it has only embarrassed the Courts in their efforts to deal with the problem." Currie, supra note 46, at 115. 
To be sure, important state interests are involved in a custody case, but a constitutional exception to the mandate of full faith and credit, offering nothing in its place, reduces the law of custody to a rule of "seize-and-run." Such a rule encourages multiple litigation by allowing each state to completely ignore a sister state's prior determination of custody. Not only is this undesirable from a federal viewpoint, ${ }^{01}$ but it is a source of potential harm to the child who is the subject of such litigation. ${ }^{62}$

Several promising alternatives to a constitutional exception have been proposed. Professor Currie, for example, urged that federal legislation is necessary to remedy the conflict of law problems in this field. ${ }^{03}$ A second alternative is to approach the problem jurisdictionally. Professor Ratner's proposed Uniform Child Custody Jurisdiction Act establishes judicial guidelines for accepting or declining jurisdiction to initially determine custody or to modify a prior decree. ${ }^{04}$ The fundamental consideration under the Act is the location of the "established home" of the child at the time the action is filed..$^{65}$ Since the only sure way of determining whether a court has jurisdiction under this Act is to bring suit and risk dismissal, one drawback is the financial burden on the litigant seeking a decree. ${ }^{60}$ Professor Ehrenzweig has proposed an

00 May v. Anderson, 345 U.S. 528, 542 (1953) (dissenting opinion).

01 See Currie, supra note 46 , at 115.

62 Commenting on this point, Professor Hazard notes: "[W]hile Justice Frankfurter [in May v. Anderson] is eloquent about the interests of the state in protecting its children, be is silent about the interest of the child who is the subject of protection. In allowing each state to decide afresh what is good for the child, we assume that the child can be the subject of inconsistent commands, and yet consistency of command is a precept in rearing children." Hazard, May v. Anderson: Preamble to Family Law Chaos, 45 VA. L. Rev. 379, 380 (1959). Professor Hazard's pessimism may be premature in view of the proposals discussed in the text accompanying notes 63-66 infra. All writers, however, concur that the basic solution will include elements of both flexibility and finality.

${ }^{03}$ Currie, supra note 46. Professor Currie believed such legislation is justifiable under article 4, $\S 1$ of the Constitution which gives Congress the power to "prescribe ... the Effect" of state decrees.

64 Professor Ratner discussed the problem, supra note 57. The proposed Act is appended to Ratner, Legislative Resolution of the Interstate Child Custody Problem: A Reply to Professor Currie and a Proposed Act, 38 So. CAL. L. Rev. 183 (1965). This proposal is criticized by Professor Curric, supra note 46, and by Professor Ehrenzweig, The Interstate Child and Uniform Legislation: A Plea for Extralitigious Proceedings, 64 MrCH. L. REv. 1 (1965).

65 "Established Home. The State in which the most recent of the following events occurred: (a) The child resided with a person acting as parent, other than a non-prevailing party, for at least six consecutive months; (h) the child resided with a non-prevailing party for a total of at least three consecutive months beyond the end of the period during which such non-prevailing party had custody pursuant to decree." Proposed UNIPORM Cando Custodx ACT $\$ 2(20)$.

${ }^{66}$ See, e.g., Sampsell v. Superior Court, 32 Cal. 2d 763, 779-80, 197 P.2d 739, 750 (1948), where the court, per Traynor, J., stated "the [interstate child custody] problem is not one of rendering custody decrees for the courts of other states to regard as final and conclusive 
efficient solution, termed "extralitigious proceedings," which calls for new methods of procedure designed specifically for custody cases and the elimination of those features of the adversary system which have proved unworkable in this field. Under this system, a court whicli determined that it should not hear a custody case could on its own motion transfer the file to a more qualified court. ${ }^{67}$

The foregoing proposals do not necessarily conflict. The ultimate solution will probably comprise two or more of these proposals. Their main thrust is a shift of emphasis away from full faith and credit concepts concerning child custody toward concepts of jurisdiction and due process. A possible solution may include nationwide service of process, a refusal to take jurisdiction of a given custody case, coupled with a transfer of that case to another forum.

Though none of these proposals is ideal, they represent attempts to solve the difficult problems of child custody while avoiding the drawbacks of the Second Restatement. Furthermore, unlike section 434c, which speaks in terms of a "judgment" and is hence overgeneralized, these proposals are strictly himited to child custody.

\section{CONCLUSTON}

Section $434 \mathrm{c}$ of the Second Restatement states a proposition contrary to the doctrine of full faith and credit to judgments. The Second Restatement relies on dicta, observations in concurring opimions (which do not control the outcome of the litigation), and dissenting opinions to justify its proposition. The Supreme Court, however, has not approved of an exception, based on the policy of the forum state, to the mandatory recognition of sister state judgments. Furthermore, it has declined to determine to what extent a custody decree is entitled to full faith and credit.

The Second Restatement seeks to create an exception to the constitutional mandate of full faith and credit which would be detrimental to our federal system. As a practical solution to the problems of child custody, it is, perhaps, the least desirable of presently available alternatives.

\section{Ronald A. Hecker †}

determinations," but rather one of jurisdiction (which may exist in two or more states concurrently); the proper test being whether the state has a "substantial interest in the welfare of the child or in the preservation of the family unit of which he is a part.'"

o7 The mechanics of this proposal are described in Ehrenzweig, supra note 64. The need for extralitigious proceedings is noted in Ehrenzweig, supra note 56, at 372. The system, originating in the Civil Law, see, e.g., $\$ 111$ of the Austrian Jurisdiktionsnorm, may be difficult to apply in our federal system. American courts are not unfamiliar with transfer proceedings, however. See 28 U.S.C. \$ 1404(a) (1964).

tLL.B., 1965, University of California, Berkeley. 